JURNAL DAKWAH DAN KOMUNIKASI

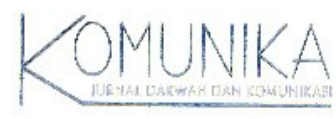

\title{
Potret Islam Sinkretisme: Praktik Ritual Kejawen?
}

\author{
Sulkhan Chakim"
}

"Penulis adalah Magister Agama (M.Ag.), dosen tetap Junsan Dakwah STA/N Purwokerto.

Abstract. Jowanese people, usually called Kejowen people, believe that all religions teach good values and spilitual puitity to reach perfection in life. They train their spilitual life and inner sense to achieve the highest existence of a human being. When the preaching of Islam came to Jowa, their rituals and religious practices were influenced by the new values of Islam. Through some dialogical processes, then occurs syncretism as a form of their religious and ritual practices. Keywords: Kejawen, itual, syncretism.

\section{PENDAHULUAN}

Pembahasan ini bermaksud mengkaji tradisi masyarakat Jawa, yang sering disebut dengan masyarakat kejawen, yang dalam hal ini, dunia mereka lebih mementingkan dunia rasa atau batin daripada dunia nyata. Oleh karena itu, memahami dunia mistik merupakan suatu perjalanan yang berangkat dari suatu pengalaman eksternal psikologis dan melibatkan kesadaran diri, yang sangat dalam.

Dunia masyarakat kejawen memiliki praktik ritual tertentu, yaitu laku batin sebagai bentuk ritual yang dilakukan oleh para pengikut atau perkumpulan kebatinan. Praktik-praktik ritual dalam tradisi Jawa, yang disebut praktik mistis tersebut sangat terlihat, khususnya di daerah atau wilayah Jawa Tengah bagian Selatan, yang sampai saat ini masih kuat. Di daerah ini, berkembang banyak varian aliran kejawen yang berkembang, corak dari sistem keyakinan dan ekspresi keberagamaan (ritual) yang tergolong unik.

Selanjutnya, ketika dakwah Islam menatap masyarakat kejawen, di sana terjadi proses dialogis dengan budaya lokal tersebut sehingga melahirkan keberagamaan "sinkretisme" yang pada gilirannya disebut Islam Abangan atau adat kejawen.

\section{AGAMA: SISTEM KEPERCAYAAN ATAU KEYAKINAN, MAGIS, RITUAL, DAN SIMBOL}

\section{Sistem Kepercayaan atau Keyakinan}

Istilah agama dianggap sebagai kata yang berasal dari bahasa Sansekerta, yang berarti “tidak kacau”. Hal itu mengandung pengertian sebagai suatu peraturan yang mengatur kehidupan manusia agar tidak kacau. Namun demikian, jika dipahami secara sosiologis, agama dimaknai sebagai gejala sosial yang umum dan dimiliki oleh seluruh masyarakat yang ada di dunia ini, dan merupakan salah satu aspek dalam kehidupan sosial sekaligus bagian dari sistem sosial masyarakat, serta sebagai suatu unsur dari kebudayaan. ${ }^{2}$ Berbeda dengan J. Milton, Yinger melihat agama sebagai suatu sistem kepercayaan dan praktik religi suatu masyarakat atau kelompok manusia yang berjaga-jaga dalam menghadapi masalah terakhir dari hidup. Senada dengan pendapat Dunlop, ia melihat agama sebagai suatu institusi atau bentuk kebudayaan yang menjalankan fungsi pengabdian kepada umat manusia.

Sistem keyakinan suatu religi atau agama dapat berwujud seperti konsep-konsep atau gagasan yang menyangkut tentang Tuhan, manusia, dan alam semesta, yaitu keyakinan yang bersifat kosmogoni (alam dunia) dan eskatologi (akhirat). Sistem ini biasanya terdapat dalam teks suci yang tertulis atau diturunkan dari generasi ke generasi berikutnya. ${ }^{3}$ 


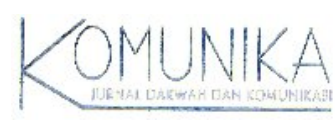

Sebagai individu dalam masyarakat, manusia dalam menjalankan agama tentunya atas dasar kesadaran diri melalui berbagai pertimbangan dalam proses kehidupannya. Pertimbangan berupa nilai-nilai menjadi suatu kepercayaan yang dimiliki setiap individu. Oleh karena itu, kepercayaan merupakan salah satu unsur yang sangat urgen dalam agama yang sangat urgen. Kepercayaan tersebut, menurut Malinowski, dapat mempengaruhi perasaan, sikap, dan hubungan yang diungkapkan tidak memiliki tujuan selain dalam dirinya sendiri, yakni dalam bentuk pemujaan yang tidak dapat dinalarkan. 4 Menurut E.Bethe, kepercayaan atau keyakinan dapat mempengaruhi sikap atau perasaan individu. Kepercayaan tersebut dapat berasal dari mitos dan rasional. Mitos merupakan bentuk pengungkapan intelektual yang primordial dari berbagai sikap dan kepercayaan keagamaan. ${ }^{5}$ Dengan mitos, manusia menghubungkan diri dengan berbagai persoalan yang berkaitan dengan lingkungan, tempat-tempat yang dianggap keramat atau suci, roh nenek moyang, ataupun cerita-cerita masyarakat yang dianggap misteri atau sesuatu yang berada di luar jangkauannya. Sistem itu yang mendasari cara pandang masyarakat terhadap keberadaan sesuatu, dan kekuatan-kekuatan yang mempengaruhi sikap perubahan yang ada.

Kepercayaan terhadap agama sangat ditentukan oleh pengalaman keagamaan seorang atau individu masyarakat. Suatu yang menarik adalah persoalan yang dianggap "suci" dalam keagamaan seseorang. Sementara itu, ide tentang sesuatu yang dianggap "suci", menurut Emile Durkheim, adalah mengkaji agama dengan membuat permisalan-permisalan dan menggolongkan semua pengalaman manusia ke dalam dua kategori yang mutlak bertentangan, yakni pengalaman yang suci dan profan. Dalam hal ini, ada beberapa karakteristik yang mempengaruhi manusia, antara lain: sesuatu yang suci sebagai aspek pengalaman atau apa yang dialami, menyerukan suatu pengakuan atau kepercayaan pada kekuasaan atau kekuatan, hal yang suci ditandai oleh kekaburan. Kekuatan suci berfungsi untuk memperkuat dan mempertahankan hidup, sikap keagamaan memperkuat penganutnya, dan meningkatkan rasa percaya diri, serta sesuatu yang suci menyampaikan kewajiban-kewajiban kepada penganut dan pemujanya. ${ }^{6}$

\section{Persoalan Magis}

Teori fungsional memandang bahwa kontribusi agama terhadap masyarakat dan kebudayaan berdasarkan pada karekteristik urgensinya, yakni transendensi pengalaman sehari-harinya terhadap lingkungan alam atau kekuatan yang berada di dunia non empiris. Teori ini memandang bahwa kebutuhan tersebut sebagai hasil dari tiga karakteristik dasar eksistensi manusia yang mencakup: pertama, manusia hidup dalam kondisi ketidakpastian; kedua, kondisi manusia dalam kaitan konflik antara keinginan dengan lingkungan atau istilah lain ketidakberdayaan manusia; dan ketiga, manusia harus hidup bermasyarakat, dan masyarakat merupakan lokasi yang teratur bagi individu dari berbagai fungsi, fasilitas, dan ganjaran, atau dengan kata lain, dihadapkan dengan kelangkaan dalam kebutuhan hidupnya. Diskusi tentang magis dan agama menunjukkan bahwa magis dapat memberikan kontribusi moral atau etika manusia karena pada kondisi tertentu manusia tidak mampu mengubah kondisi yang dipandang mengecewakan, atau bahkan tak berdaya. Dengan bantuan kekuatan adikodrati diharapkan dapat menyelesaikannya. Fungsi magis ini ditentukan oleh Malinowski, tidak melemahkan hubungannya dengan struktur dan proses sosial. ${ }^{8}$

Persoalan magis dalam agama merupakan unsur yang lazim adanya dan menjadi suatu yang unik diperdebatkan. Dalam magis, ada seperangkat kegiatan manusia yang agama dan dengan magis dimungkinkan manusia bisa menyesuaikan diri dengan kekecewaan, deprivasi, frustrasi, penyakit, dan kematian. Usaha-usaha manusia untuk mengatasi persoalan tersebut, selalu berhubungan roh-roh yang dianggap suci, dan bahkan dengan menggunakan kesaktian, baik berupa jimat atau benda yang dianggap memiliki kekuatan.

Kadangkala dengan pendekatan upacara keagamaan ritus magis yang dilakukan oleh para pemuka, maupun pemeluk setia suatu agama dalam rangka untuk memecahkan setiap persoalan yang dihadapi. Kegiatan ritus tersebut sebagai upaya penegasan, bahwa norma-norma keagamaan dapat dijadikan sebagai landasan berpikir dalam menyelesaian suatu masalah. Jadi, dengan norma agama magis dapat berfungsi sebagai pengendali sosial yang sangat positif.

\section{Persoalan Ritual dan Sistem Simbol}




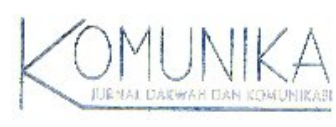

Agama-agama yang datang di tanah Jawa sebelum agama Islam sangat berpengaruh terhadap adat-istiadat, pandangan hidup, sistem keyakinan, dan berbagai tata-cara keagamaan dalam kehidupan sehari-harinya. Beberapa fenomena yang muncul dari kepercayaan mereka adalah kepercayaan pemujaan terhadap para dewa, atau para dayang, dan berbagai hantu. Kepercayaan dan praktik keagamaan ini dapat dilihat pada kegiatan upacara atau ritual dan sesaji sebagai simbol ketaatan kepada para dewa. Dalam jenis sesajian ini, setidaknya masyarakat Jawa pada ummnya mengenal 4 (empat) jenis sesajian," antara lain: (1) sesajian dalam bentuk selamatan yang diperuntukkan kepada para roh-roh yang dianggap suci dan dihormati, (2) sesajian dalam bentuk penulakan. Sesajian yang bertujuan untuk menolak mara bahaya dari pengaruh ro-roh jahat, (3) sesajian dalam bentuk Wadima. Sesajian yang dilakukan secara rutin yang diperuntukkan para wali, jin-jin, bidadari, dan lainlain, dan (4) sedekah sesajian berupa makanan yang bertujuan untuk keselamatan orang yang sudah meninggal.

Unsur agama tidak lepas dari pemujaan (cult) yang merupakan sarana untuk berkomunikasi dengan objek tertentu yang dianggap suci. Sebagaimana yang diungkapkan oleh Malinowski, bahwa perasaan, sikap, dan hubungan yang memiliki nilai misteri yang terkait dengan dirinya sehingga tidak dapat dirasionalisasikannya. ${ }^{10}$

Sementara itu, teori W Robertson Smith (1846-1894) membahas tentang sesaji. Menurut pendapatnya, masalah sesaji ini perlu diteliti di samping masalah subtansi keyakinan. Pendapatnya, sesaji menarik jika dilihat dari sisi ritualnya yang ajeg, sementara doktrinnya berubah. Di samping itu, pelaksanaan ritualnya memiliki makna sosial yang amat tinggi. Sebagian pelakunya ada yang sadar bahwa ini adalah "perintah" atau tuntutan dan atas keyakinannya, tetapi ada juga yang melaksanakannya karena sudah menjadi tradisi atau kebiasan anggota masyarakatnya."

Selanjutnya, menurut Preusz, sesaji atau ritual ini dilakukan karena keterbatasan manusia sehingga mereka melakukan tindakan-tindakan untuk keperluan hidupnya. ${ }^{2}$ Akan lebih jauh lagi fungsinya, jika diperdepatkan oleh pendapat Gennep, dalam bukunya dalam Pessage de Rites, mengatakan bahwa ritus-ritus dan upacara religi pada dasarnya berfungsi sebagai penyemangat kehidupan. Penyemangat dalam bentuk ritus-ritus juga biasa diberikan kepada tahap-tahap pertumbuhan individu seperti lahir, kanak-kanak, menikah, menjadi tua, hingga meningggal dunia. ${ }^{13}$

Dalam pandangan Gennep, bahwa ritus dan upacara itu dibagi menjadi tiga, yakni pertama, perpisahan (sparation), ritus ini dalam bentuk upacara kematian. Kedua, peralihan (marge), adalah ritus yang berkaitan dengan peralihan tahap seperti upacara hamil tujuh bulan atau mithoni. Ketiga, integrasi. Upacara kegiatan ini seperti dalam acara selamatan kelahiran, pernikahan, dan pergantian musim. ${ }^{4}$

\section{KEAGAMAAN ORANG JAWA ATAU KEJAWEN}

Masyarakat atau sekelompok manusia yang terlembaga pasti memiliki pandangan tertentu terhadap keyakinan agamanya, seperti halnya orang Jawa. Sebagian orang Jawa memandang bahwa semua agama itu sama baiknya karena seluruh agama mengajarkan keluhuran budi dan kesucian rokhani untuk mendapatkan kesempurnaan hidup. Bagi orang Jawa, yang dalam hal ini disebut dengan kejawen, adalah masyarakat yang memiliki pendekatan kebatinan atau rasa dalam diri manusia untuk mencapai eksistensi yang tinggi sebagai manusia. Tentunya, mencakup pandangan orang Jawa terhadap dunia Jawa, laku, dan olah batin bagi kejawen.

Manusia diciptakan oleh Tuhan sebagai ciptaan yang terbaik karena kesempurnaannya yang tidak dimiliki oleh makhluk lainnya. Dengan berbagai kelebihannya, manusia yang pada dasarnya memiliki fitrah, yaitu bahagia. Kesempurnaan manusia adalah takdir bawaan yang memerlukan hubungan yang harmonis antara kesadaran dengan kasih sayang Tuhan.

Sementara itu, manusia sebagai makhluk yang terdiri dari fisik dan psikis, sebagaimana dinyatakan oleh Magnis Suseno, bahwa pandangan dunia Jawa bertolak dari perbedaan antara dua segi fundamental realitas, yaitu segi lahir dan segi batin.5 Segi batin dalam pandangan orang Jawa atau kejawen merupakan sikap subjektivitas atau lebih ditekankan pada rasa dalam pencapaian kesempurnaan. Oleh karena itu, semakin tinggi kekuatan rasanya, maka kebenaran dalam kesempurnaan akan semakin tajam.

Kaitan dengan masalah lahir dan batin, Niels Mulder menyatakan bahwa inti penting dari kejawen adalah kebatinan, yaitu elaborasi kehidupan batin dan diri manusia. ${ }^{16}$ Dengan demikian, orang kejawen memiliki tujuan yang tertinggi sebagai 


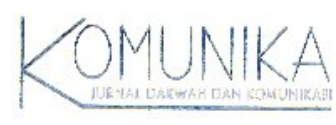

manusia yang memiliki kesempurnaan hidup melalui praktik olah batin. Olah batin sebagai proses harmonisasi menuju ketenangan, kebahagiaan, dan kejujuran dalam hidup untuk menuju sangkan paran kang dumadhi.

Salah satu aliran kejawen, yaitu Pangestu memiliki ajaran Trisila, yang merupakan ajaran penyembahan dari hati dan pikiran terhadap tripurusa. Ajaran Trisila adalah Eling yang berarti sadar atau ingat. Kesadaran berarti membuat manusia merasa bahwa dirinya ada dan sedang melakukan sesuatu. Eling kepada Tripurusa berarti ingat bahwa manusia mempunyai kewajiban untuk selalu taat kepada Tuhan Sang Pencipta. Pracaya, yaitu sesuatu yang mutlak diperlukan, jika manusia ingin menyatu dengan Tuhan. Mituhu, berartitaat melaksanakan perintah Tuhan. ${ }^{17}$

Sementara itu, kelompok Cahyo Buwono memiliki pandangan keagamaan lebih mengutamakan hasil penghayatan, yang diwujudkan pada tindakan yang baik dan berguna bagi kemaslahatan orang banyak dan merasa sebagai kawula dan ciptaan Tuhan. Tuhan adalah Sang Pencipta Alam Semesta yang disebut Gusti Ingkang Murbeng Dumadi.18

Berdasarkan hasil penelitian Sulkhan Chakim, ${ }^{19}$ ada pandangan dan praktik ritual masyarakat kejawen, sebagai berikut:

Keyakinan kepada Tuhan Yang Maha Esa dalam terminologi kejawen disebut dengan Gusti Allah. Komunitas adat kejawen Kalisalak mempercayai Gusti Allah yang mengatur alam semesta dan memberi kehidupan di dunia ini, menurut mantan Ki Kunci Ritam:

"Gusti Allah niku mboten wonten wrjude, Gusti sing wrijud lan sing ora wrijud. Sing ora wrjud kula percaya marang awake dhewe, artine Gusti Allah iku ana ing awake dhewe" (Tuhan itu tidak berwujud, Tuhan yang berwujud dan yang tidak berwujud. Yang tidak berwujud, saya percaya kepada diri sendiri artinya Tuhan itu ada dalam hati kita).

Pencarian kepada Tuhan Yang Maha Kuasa dilakukan dengan berbagai laku atau nyepi di makam-makam yang dianggap keramat, bahkan berdasar pengakuan Ki Kunci Ritam, sebagai berikut:

"Kaurula sering mlampah dumugi Tasik, Bandung lajeng kaurla sowan wonten makam-makam utawi kuburankuburan ing tanah Jawi. Lelampah tujuanipun kagem pados wangsit.” (Saya sering jalan kaki sampai Tasik, Bandung, dan nyepi ke makam-makam para wali di tanah Jawa. Laku tersebut tujuannya untuk mencari kebijaksanaan).

Selanjutnya, keyakinan kepada Tuhan Yang Maha Esa itu juga menurut pengakuannya, bahwa bacaan syahadat itu ada dua, yaitu:

"Asyhadu an lailaha illah wa asyhadu anna Muhammadurrasulullah dan Asyhadu an lailaha illah asyhadu anna Muhammadarrasulullah".

Syahadat yang memakai "wa" itu syahadatnya orang Jawa. Adapun yang tanpa "wa" untuk orang Arab. Ketika ditanya mengapa demikian:

"Sebab syahadat ingkang ngagem wa niku ingkang gadah watu Bechug, tapi tampa wa ingkang gadah watu gummg utawa Prabu Gumung tegese watugumung nikutiyang-tiyang Arabingkang seneng berbuatonar lanangkara murka, seneng perang”

Selain keyakinan kepada Tuhan Yang Maha Esa, ada media atau perantara yang dalam setiap kegiatan ritual komunitas adat kejawen ini, adalah Mbah Kajoran. Ia tokoh yang sangat diagungkan dan memiliki pengaruh dalam sistem kepercayaan anak putu. Oleh karena itu, dalam setiap hajatan atau perlon, Mbah Kajoran menjadi sangat penting meskipun sudah meninggal ratusan tahun yang silam. Bahkan, ketika berdoa Mbah Kajoran selalu dijadikan perantara khususnya dalam prosesi ujudan. Adapun teks ujudan sebagai berikut:

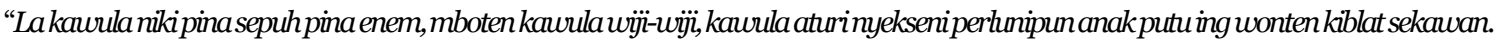
Jaler esteri, pina sepuh-pina enem, saresening kawula resik kubuan Mbah Kajoran. La menika badhe slametan tumpeng suci wonten pagelaran. Kaurula aturinyekseni perhmipun anakputu sing wonten keblat sekawan. Mugi-mugiha saresening kaurula sampum myekar kaki-

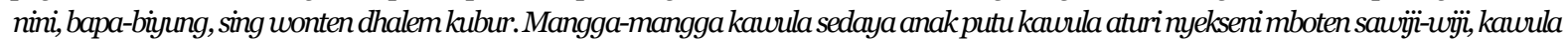
aturimyekseni....nggüh."

Teks ujudan dalam ritual yang dilakukan dalam lingkaran hidup manusia selalu bersandar pada kekuatan-kekuatan yang ada dalam lingkungannya sebagai perantara untuk sampai pada harapannya. Dalam prosesi tersebut, selalu dikaitkan dengan selamatan, perlon di tempat-tempat yang dianggap keramat oleh komunitasnya. 
Secara teoretis, bahwa ritual sesaij, selamatan, perlon, dan kegiatan-kegiatan lingkaran hidup tersebut menurut Gennep, sebagai upaya penyemangat hidup dalam menghadapi tantangan dan kesulitan hidup masyarakat Jawa pada waktu itu dan hingga dewasa ini.

\section{SIMPULAN}

Segi batin dalam pandangan orang Jawa atau kejawen merupakan sikap subjektivitas atau lebih ditekankan pada "rasa" dalam pencapaian kesempurnaan hidup menjadi semakin tinggi kekuatan rasanya, maka kebenaran dalam kesempurnaan akan semakin tajam. Olah batin sebagai proses harmonisasi menuju ketenangan, kebahagiaan, dan kejujuran dalam hidup untuk menuju sangkan paran kang dumadhi.

Praktik-praktik ritual ditingkat realitas masyarakat sangat dipengaruhi oleh pemegang otoritas tokoh yang dianggap suci dan sebagai perantara dalam berhubungan dengan Gusti Ingkang Murbeng Dumadi.

Berbagai bentuk doa dalam proses ritual banyak menggunakan teks-teks syahadat, shalawat Nabi, lafaz hamdalah yang bersentuhan dengan teks-teks kejawen. Kemungkinan sekali praktik doa pada waktu itu dilakukan untuk mengubah pada subtansi sandaran kepada Allah SWT.

\section{ENDNOTE}

${ }^{1}$ Dadang Kahmad, Sosiologi Agama (Bandung: Remaja Rosdakarya, 2000), hal. 13-14.

2 lbid., hal. $43-46$.

${ }^{3}$ George Herbert Mead, Mind, Self and Society, Charles W. Moris (Ed.) (Chicago: University of Chicago Press, 1934), hal. 296.

${ }^{4}$ Ibid., hal. 144.

${ }^{5}$ Thomas F. O'Dea, hal. $37-38$.

${ }^{6} /$ bid., hal. $7-8$.

7 lbid., hal 8-10.

${ }^{8}$ Capt R.P. Suyono, Dunia Mistik Orang Jawa (Yogyakarta: LKiS, 2007), hal. 131-132.

${ }^{9} /$ lbid., hal. 74-75.

${ }^{10}$ Koentiaraningrat, Asas-asas Ritus, Upacara, Religi dalam Ritus Peralihan Indonesia (Jakarta: Balai Pustaka, 1993), hal. 2425.

${ }^{11}$ Ibid., hal. 26.

${ }^{12} \mathrm{Ibid}$, , hal. 32.

${ }^{13} /$ lbid., hal. 34 .

${ }^{14}$ F. Magnis Suseno, Etika Jawa (Jakarta: Gramedia Pustaka Utama, 2001), hal. 117-118.

${ }^{15}$ N. Mulder, Agama, Hidup Sehari-hari dan Penubahan Budaya; Jawa, Muangthai, dan Filiphina (Jakarta: Gramedia Pustaka Utama, 1999), hal. $62-$ 63.

${ }^{16}$ Soehada, Orang Jawa Memaknai Agama (Yogyakarta: Kreasi Wacana, 2008), hal. 96-99.

${ }_{17}^{17}$ Tjaroko HP teguh Pranoto, Spinitualitas Kejawen: IImu Kasunyatan Wawasan \& Pemahaman Penghayatan \& Pengamalan (Yogyakarta: Kunt Press, 2007), hal. 75-77.

${ }^{18}$ Sulkhan Chakim (hasil penelitan), Komunitas Adat Kejawen; Studi Ethnografi Sistem Kepercayaan dan Relasi Sosialnya, 2008.

\section{DAFTAR PUSTAKA}

Capt. R.P. Suyono. 2007. Dunia Mistik Orang Jawa. Yogyakarta: LKiS.

Chakim, Sulkhan. 2008. Komunitas Adat Kejawen; Studi Ethnografi Sistem Kepercayaan dan Relasi Sosialnya. P3M STAIN Purwokerto.

F. O'Dea. Thomas.1990. Sosiologi Agama; Suatu Pengantar Awal. Jakarta: Raja Wali Press.

Herbert Mead. George. 1934. Mind, Self and society, Charles W. Moris (Ed.). Chicago: University of Chicago Press.

H.P. Teguh Pranoto, Tjaroko. 2007. Spintualitas Kejawen: IImu Kasunyatan Wawasan \& Pemahaman Penghayatan \& Pengamalan. Yogyakarta, Kunt Press.

Kahmad, Dadang. 2000. Sosiologi Agama. Bandung: Remaja Rosdakarya. 
Koentjoroningrat. 1993. Asas-asas Ritus, Upacara, Religi dalam Ritus Peralihan Indonesia. Jakarta, Balai Pustaka Magnis Suseno. F. 2001. Etika Jawa. Jakarta: Gramedia Pustaka Utama.

Mulder, N. 1999. Agama, Hidup Sehari-hari dan Perubahan Budaya; Jawa, Muangthai, dan Filiphina. Jakarta: Gramedia Pustaka Utama. Soehada. 2008. Orang Jawa Memaknai Agama. Yogyakarta: Kreasi Wacana. 